\title{
The exploration of in-service training needs of psychiatric nurses
}

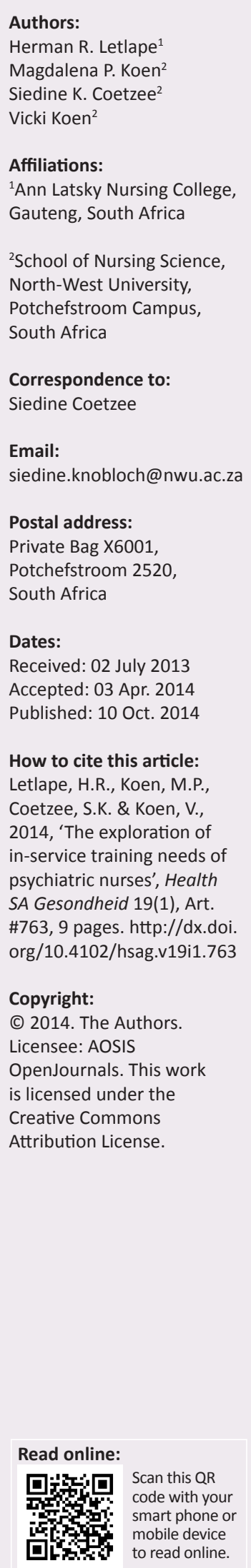

Background: New research findings, changes in legislation and the use of information technology in nursing, require continuous in-service training of psychiatric nurses to cope with, reflect on and modify their clinical practice based on emerging knowledge. Many international studies have been conducted on the importance of in-service training and authors agree that in-service training improves the quality of nursing care. However, few studies have been conducted on in-service training in South Africa and psychiatric nursing.

Objectives: The objectives of the study were to explore and describe the needs and benefits of in-service training for psychiatric nurses; and to formulate recommendations for in-service training.

Method: The research project followed a qualitative, explorative, descriptive and contextual approach. Six focus group interviews were conducted and the following questions were asked: 'What are your in-service training needs as psychiatric nurses?', 'What are the benefits of doing in service training?' and 'What can be done to ensure that in-service training is done continuously?' Data were analysed through the use of content analysis and Tesch's eight steps of data analysis were used.

Results: The findings of this research included three main themes, namely, that on-going inservice training is necessary, in-service training is beneficial to psychiatric nurses and that challenges exist with regard to in-service training.

Conclusion: The findings confirmed the need for ongoing in-service training which has many advantages for psychiatric nurses. Aspects that hinder in-service training need to be addressed by planning ahead and by implementing the recommendations as identified by the psychiatric nurses and their managers.

Agtergrond: Nuwe navorsingsbevindinge, veranderinge in wetgewing en die gebruik van inligtingstegnologie in verpleegkunde, vereis deurlopende indiensopleiding van psigiatriese verpleegkundiges om hulle kliniese praktyk soos gebaseer op opkomende kennis, te hanteer, daarop te reflekteer en dit aan te pas. Internasionaal is daar baie studies gedoen oor die belang van indiensopleiding en outeurs stem saam dat indiensopleiding die kwaliteit van verpleegsorg verbeter. Daar is egter nog net 'n paar studies oor indiensopleiding in SuidAfrika en psigiatriese verpleegkunde gedoen.

Doelwitte: Die doelwitte van die studie was om die behoeftes en voordele van indiensopleiding vir psigiatriese verpleegkundiges te verken en te beskryf en om aanbevelings te formuleer vir indiensopleiding.

Metode: Die navorsingsprojek het' $n$ kwalitatiewe, verkennende, beskrywende en kontekstuele benadering gevolg. Ses fokusgroeponderhoude was gedoen en die volgende vrae was gevra: 'Wat is jou indiensopleiding behoeftes as 'n psigiatriese verpleegkundige?', 'Wat is die voordele daarvan om indiensopleiding te doen?' en 'Wat kan gedoen word om te verseker dat indiensopleiding deurlopend gedoen word?'. Data was ontleed deur die gebruik van Tesch se agt stappe van data analise.

Resultate: Die bevindinge van die navorsing sluit drie hooftemas in, naamlik, dat deurlopende indiensopleiding is nodig, indiensopleiding is voordelig vir psigiatriese verpleegkundiges en daar is verskeie uitdagings in indiensopleiding.

Gevolgtrekking: Die bevindinge bevestig die behoefte aan indiensopleiding wat baie voordele het vir psigiatriese verpleegkundiges. Aspekte wat indiensopleiding verhinder moet aangespreek word deur vooruit te beplan en deur aanbevelings, soos geïdentifiseer deur psigiatriese verpleegkundiges en hulle bestuurders, te implementeer. 


\section{Introduction}

Psychiatric nursing is continuously changing, much like the other nursing fraternities. The changes are brought about by new research findings, for example, the formulation of atypical anti-psychotic drugs which are producing less severe side effects compared with the typical anti-psychotic drugs which were used before the establishment of these new drugs (Keltner, Bostrom \& McGuinness 2011:244). There have also been changes in South African legislation, for example, the Mental Health Act 18 of 1973, which emphasised hospital care, was amended and the new Mental Health Act 17 of 2002, which emphasises community-based care, was promulgated (Uys \& Middleton 2004:89). Similarly, health systems on a global scale are undergoing vast change as a result of emerging challenges such as transitions in epidemiology and demography, innovation in technology, growing population demands and professional differentiation (Frenk et al. 2010:7). All these changes require psychiatric nurses to be continuously in-service trained in order to cope with the demands of nursing services (Booyens 2008:384; Muller 2009:294).

\section{Background}

In-service training is one of the activities in the workplace that keeps nurses informed and equips them to perform to the best of their abilities (Muchinsky, Schreuder \& Kriek 2003:167). In-service training is defined by Muller (2009:351) as the informal training of nurses to improve their professional knowledge, skills and attitudes according to the demands of the nursing unit and, according to Abruzzese (1996:3), is the key to quality nursing care. The purpose of in-service training, according to Muller (2009:351), is to facilitate the more effective functioning of nurses within a team context in a unit, to rectify shortcomings in the nurses' knowledge, skills and attitudes, to prepare the nurses for the changes that are implemented by the nursing service and to manage risks before complications arise. According to Booyens (2008:384), the quality of patient care rendered by nurses can be related directly to their knowledge and skills. Nursing managers who invest in ongoing in-service training are rewarded with better patient care as the nurses become more motivated to perform to the best of their ability (Booyens 2008:384; Erasmus et al. 2009:3).

According to Willets and Leff (2003:237), in-service training increases the psychiatric nurse's knowledge and skills with regard to the management of psychiatric patients. Keltner et al. (2011:117) state that the psychiatric nurse uses both verbal and non-verbal communication skills as a primary therapeutic agent, compared with the procedures and physical interventions used by the medical-surgical nurse. Psychiatric nurses thus need continuous in-service training in order to update their knowledge on treatment procedures and to ensure consistent, quality patient care in the demanding psychiatric nursing field (Bloor et al. 2004:39-41).

Internationally, much research has been conducted in psychiatric nursing. Bloor et al. (2004:39) investigated the impact of training courses on psychiatric nurses in Russia. The focus of the project was to develop a cultural change in the management of violence and aggression, as well as the professionals' ability to question existing practice and to develop new methods of treatment and training. The need for training of psychiatric nurses in the management of aggression and violence was identified and nurses were identified as potent agents for organisational change with regard to the questioning of old practices and welcoming new methods of treatment and training.

In England, Willets and Leff (2003:237-243) investigated the efficiency of a staff training programme for the improvement of the knowledge and skills of psychiatric nurses. A staff training programme was adopted and conducted over 10 sessions, addressing a wide range of issues relating to the management of mentally-ill patients. The impact of the programme was examined using both a knowledge questionnaire and a semi-structured questionnaire to explore the range and usage of management strategies by nurses. The main conclusion was that the training programme was effective in increasing the knowledge and skills of psychiatric nurses. In further studies in England, Munro, Watson and McFadyen (2006), Lam, Kuipers and Leff (1993:233-237) and Gournay (2000:243-249) all found that in-service training increases the knowledge and skills of staff members and should be used in a variety of psychiatric nursing hospitals.

In Switzerland, Needham et al. (2005:649-655) investigated the effect of a training course in aggression management on psychiatric nurses' perceptions of aggression. At that time it was not clear from the literature whether psychiatric nurses' attitudes toward patients' aggression influenced the formers' behaviour toward the latter. So also, it was unclear whether the enhanced capacity of psychiatric nurses to cope with aggressive patients would nurture positive attitudes and alleviate adverse feelings emanating from patients' aggression. However, findings from the study indicated improvement in the psychiatric nurses' perceptions of patients' aggression after receiving a training course in aggression management. This result confirms the importance of in-service training for psychiatric nurses.

Nationally, a number of studies have been conducted on inservice training for nurses. The most recent study, conducted by Norushe et al. (2004:63), investigated in-service training as experienced by registered nurses and midwives and noted that newly-appointed registered nurses on probation reported not receiving in-service training for six months or longer, yet they were still expected to perform their tasks efficiently. Other studies conducted in nursing in South Africa date back as much as 20 years. Harrington (1989:28-31) investigated in-service training in a private general hospital. His findings revealed that there was a declining emphasis on professional development and in-service training of nurses, although it was identified as being of utmost importance by the nurses themselves. Delport, Greenfield and Carolus (1989:26-27) also investigated in-service training and conclusions from this study highlighted the fact that in- 
service training improves the quality of nursing care. It can thus be concluded that in-service training is receiving less and less attention in practice, although it is considered to be invaluable for nurses and midwives in practice.

The only study conducted in psychiatric nursing in South Africa was done by Nel (1986), who investigated the effect of in-service training on the quality of psychiatric nursing care for mentally-retarded patients. The conclusion was that psychiatric nurses working in centres for mentally-retarded patients should receive continuous in-service training in order to improve the quality of care they render to these patients. It becomes clear from this literature review that inservice training is considered to be fundamental to nursing; and both international and national literature exemplifies the positive influence that in-service training has on nurse, patient and quality care outcomes. However, national literature shows that this is not implemented readily in practice. National studies are few and outdated, with the last study in psychiatric nursing having been done in 1986, as stated above, thus highlighting the absolute importance and necessity of this study.

\section{Objectives}

- To explore and describe the in-service training needs of psychiatric nurses in a selected psychiatric hospital in Gauteng.

- To explore and describe the benefits of in-service training for psychiatric nurses in that selected psychiatric hospital.

- To formulate recommendations for in-service training for psychiatric nurses.

\section{Contribution to field}

A plethora of international research has been conducted on the importance of in-service training, with authors agreeing that in-service training improves the quality of nursing care. Nationally, a number of studies have been conducted on inservice training for nurses; however, the majority of these studies were conducted prior to 1990 and were not related to psychiatric nursing. This study aimed to increase the awareness of the needs and benefits of in-service training of psychiatric nurses and to formulate recommendations for inservice training for psychiatric nursing.

\section{Research method and design \\ Design}

A qualitative research design with explorative, descriptive and contextual strategies was used.

\section{Context}

This study was conducted in Gauteng which is the most populated province in South Africa, with a population density of 10.5 million (Statistics South Africa 2011). Gauteng has three main psychiatric hospitals, one of the biggest of which was selected for this study. The hospital has a bed capacity of over 600 beds and employs over 100 psychiatric nurses. Patients who are admitted to this hospital are suffering from different mental conditions which include schizophrenia, bipolar mood disorder, anxiety disorders and substance-related psychosis.

\section{Procedure}

The procedure followed to collect data is explained in the following paragraphs.

\section{Population and sampling}

The target population of this study was psychiatric nurses working in a selected psychiatric hospital in Gauteng.

\section{Sampling method}

Purposive sampling as described by Macnee (2004:107) was used in order to select participants from the identified population. The researcher, with the assistance of the training coordinator, selected psychiatric nurses who were knowledgeable about in-service training. Participants met the following inclusion criteria:

- Psychiatric nurses employed by Gauteng Department of Health as psychiatric nurses in a selected psychiatric hospital, who had a minimum of at least six months' clinical experience in psychiatric nursing.

- Psychiatric nurses registered with South African Nursing Council as professional nurses.

- Psychiatric nurses willing to be audio taped during focus group interviews.

\section{Sample size}

A total of 28 psychiatric nurses participated in the study.

\section{Data collection}

The nursing manager delegated a training coordinator to assist in the selection of psychiatric nurses who met the selection criteria as explained in the sampling method. The nursing manager also agreed to release participants for one to two hours in order for them to participate in the study on the day of data collection. Flyers with information were distributed to different wards, the purpose of which was to inform psychiatric nurses about the study and its aim. The researcher had individual discussions with the psychiatric nurses who met the selection criteria. The aim of the discussion was to obtain the contact details of potential participants so as to keep participants informed about dates and times for focus group interviews and to provide participants with an opportunity to ask questions related to the study (Burns \& Grove 2009:514). The training coordinator assisted with the recruitment of participants and in grouping them according to their experience, in order to facilitate open discussions (Burns \& Grove 2005:543; Morgan 1998:9).

Six focus group interviews, inclusive of the trial run, were conducted and data saturation was reached, which means the focus group interviews were conducted until the nurses' 
information about in-service training needs and benefits became repetitive and redundant (Macnee 2004:116). Five psychiatric nurses participated in all except the third and fourth focus group interviews, where only four psychiatric nurses participated.

The aims of the focus group were clarified before interviews began. Participants were encouraged to express their views about the interviews and topic. The participants were made aware of the fact that all points of view were valid and helpful and that there was no need to defend points that arose from the interviews. The researcher clarified his role to the participants, namely, to facilitate, but not contribute, to the group interviews. On the day of data collection, consent forms were obtained from the participants for their participation in the study, after which focus group interviews were conducted.

Questions that made participants take a stand with regard to defending their point of view were avoided, for example, asking 'Why will this point of view make the difference?' instead of 'How will this point of view make the difference?' (Burns \& Grove 2005:543). The session was opened by providing an opportunity for participants to express their views about the topic of discussion (Burns \& Grove 2005:543; Polit \& Beck 2006:342), after which the following questions were asked:

- What are your in-service training needs as psychiatric nurses?

- What are the benefits of doing in-service training?

- What can be done to ensure that in-service training is done continuously?

Communication techniques, as described by Kneisl and Trigoboff (2009:206-212), were used during the focus group interview in order to explore and describe the in-service training needs of psychiatric nurses. Field notes were taken after each focus group interview.

\section{Trial run}

A trial run was conducted on a small scale in preparation for the research to test the applicability of the questions for the main interview and the communication skills of the researcher. A group of five psychiatric nurses was included in the trial run focus group interview. The study leaders were given the transcribed interviews and the questions asked during the trial run. They suggested more probing in the manner in which questions were asked and made suggestions which could be used to obtain more information for further data collection.

\section{Analysis}

An independent, experienced co-coder was appointed to help analyse the data. Coding was done according to the combination of steps proposed by Tesch (quoted in Creswell 1994:154-155). After independent coding, the researcher and co-coder had a consensus discussion about the findings.
Conclusions were formulated by synthesising the findings and the relevant literature and recommendations were formulated for nursing practice.

\section{Results \\ Findings}

The research findings emanated from the responses of the participants to the research questions. Three main themes emerged from the responses of the psychiatric nurses to these questions (see Box 1).

The main objective of the study was to explore and describe the in-service training needs and benefits to psychiatric nurses in a selected psychiatric hospital in Gauteng. The three themes that emerged from the responses of psychiatric nurses to the interview questions were then divided into subthemes, where applicable, and are outlined below.

\section{Theme 1: Ongoing in-service training is necessary}

The participants raised aspects which confirmed that psychiatric nurses need on-going in-service training. Aspects

BOX 1: Overview of the main themes and subthemes.

\begin{tabular}{|c|c|}
\hline $\begin{array}{l}\text { Question } 1 . \\
\text { What are your in-service training } \\
\text { needs as psychiatric nurses? } \\
\text { Theme } 1 \text { : } \\
\text { Confirmed need for on-going in-service } \\
\text { training }\end{array}$ & $\begin{array}{l}\text { 1. Keeping up to date with new } \\
\text { developments and information. } \\
\text { 2. The reinforcement and recalling } \\
\text { of old information. } \\
\text { 3. To be empowered with } \\
\text { knowledge and skills. } \\
\text { 4. Providing an opportunity to share } \\
\text { knowledge and information with } \\
\text { others. }\end{array}$ \\
\hline $\begin{array}{l}\text { Question } 2 \text {. } \\
\text { What are the benefits of doing } \\
\text { in-service training? } \\
\text { Theme } 1 \text { : } \\
\text { Career advantages }\end{array}$ & $\begin{array}{l}\text { 1. Empowerment. } \\
\text { 2. Rendering of quality care. } \\
\text { 3. Improving working relationships. } \\
\text { 4. Creating a therapeutic } \\
\text { environment. } \\
\text { 5. Encouraging staff members to } \\
\text { study further. } \\
\text { 6. Keeping up to date with new } \\
\text { information. } \\
\text { 7. Increasing staff motivation. } \\
\text { 8. Ability to work independently. }\end{array}$ \\
\hline $\begin{array}{l}\text { Question } 2 . \\
\text { Theme 2: } \\
\text { Social advantages }\end{array}$ & $\begin{array}{l}\text { 1. Gaining respect from others. } \\
\text { 2. Understanding how to relate to } \\
\text { others. }\end{array}$ \\
\hline $\begin{array}{l}\text { Question } 2 \text {. } \\
\text { Theme 3: } \\
\text { Physical advantages }\end{array}$ & $\begin{array}{l}\text { 1. Decrease in staff injuries. } \\
\text { 2. Decrease in patient injuries. }\end{array}$ \\
\hline $\begin{array}{l}\text { Question } 2 . \\
\text { Theme 4: } \\
\text { Psychological advantages }\end{array}$ & $\begin{array}{l}\text { 1. A feeling of more confidence. } \\
\text { 2. An increased ability to manage } \\
\text { stress and anxiety. }\end{array}$ \\
\hline $\begin{array}{l}\text { Question } 3 \text {. } \\
\text { What can be done to ensure that } \\
\text { in-service training is done continuously? } \\
\text { Theme 1: } \\
\text { Recommendations for the improvement } \\
\text { of in-service training }\end{array}$ & $\begin{array}{l}\text { 1. Involve staff regarding their } \\
\text { needs for in-service training. } \\
\text { 2. Relevant training based on needs. } \\
\text { 3. Recent and interesting topics. } \\
\text { 4. Exemplary and proactive } \\
\text { management. } \\
\text { 5. In-ward in-service training. } \\
\text { 6. Centralised in-service training. } \\
\text { 7. Trainers must improve their } \\
\text { presentation. } \\
\text { 8. Learning resources should be } \\
\text { made available. } \\
\text { 9. Planning for in-service training. } \\
\text { 10. Invite external presenters or } \\
\text { experienced presenters. }\end{array}$ \\
\hline $\begin{array}{l}\text { Question } 3 . \\
\text { Theme } 2 \text { : } \\
\text { Factors which hinder in-service training }\end{array}$ & $\begin{array}{l}\text { 1. Needs of staff neglected. } \\
\text { 2. Lack of motivation from staff. } \\
\text { 3. Repetition of same topics in in- } \\
\text { service training. } \\
\text { 4. No opportunity for staff to } \\
\text { express their needs with regard } \\
\text { to in-service training. } \\
\text { 5. Limited resources. } \\
\text { 6. Lack of planning. }\end{array}$ \\
\hline
\end{tabular}


raised included: keeping up to date with new developments and information (16 reports), the reinforcement and recalling of old information (six reports), the need to be empowered with knowledge and skills (eight reports) and providing an opportunity to share knowledge and information with others (five reports). The following quotations give an indication of this theme. The codes used to identify the participants, as well as the page of the transcript that the quotation can be found, are ' $\mathrm{f}$ ' (focus group) and ' $\mathrm{p}$ ' (page):

'What I think is that the person with certain information about a certain procedure or something that is done wrongly has to share information. We need to keep ourselves up to date with recent information that is needed so that we do things correctly.' (f3, p6)

'... [I]t is important to do in-service training regularly ...' (trial run, p5)

'I believe without proper in-service training to update us ... we would not be able to share our expertness [sic] with our students ...' (f2, p3)

Booyens (2008:386-390) confirms that in-service training programmes are directed towards bringing psychiatric nurses up to date with new diagnostic and treatment techniques, the care and operation of new equipment, the optimal use of supplies and new institutional policy decisions. Muller (2009:351) further mentions that psychiatric nurses who are kept up to date with new information are able to function effectively within a team context in the unit.

\section{Theme 2: In-service training is beneficial to psychiatric nurses}

The participants indicated that in-service training proved to be beneficial for them and included career advantages, social advantages, physical advantages and psychological advantages.

\section{Career advantages}

The participants raised many reasons as to why they considered in-service training to be advantageous to their career. These included: empowerment (15 reports), the rendering of quality care (seven reports), improvement in work relationships (14 reports), encouragement for further study (five reports), creation of a therapeutic environment (20 reports), increasing staff motivation (six reports), keeping up to date with information (four reports) and the ability to work independently (eight reports). The following quotes clarify this theme:

\footnotetext{
"...[T]he more you learn the more you are empowered. If somebody knows the technique ... does that effectively in short time and there will be less or no injuries on that patient and to you. Also in-service training helps again for someone to be able to identify the needs for further training in other courses outside and inside the institution.' (f3, p10)

' $[\mathrm{I}] \mathrm{n}$-service education boosts your confidence and you become more productive at work ...' (f3, p3)

'In-service training also gives us the knowledge on how to deal with subordinates ...' (f2, p4)
}

Literature confirms that in-service training includes guiding, directing and assisting psychiatric nurses with regard to doing their duties effectively and in the development of their careers, which ensures their empowerment in the workplace (Booyens 2008:386-390). Swanepoel, Erasmus and Schenk (2008:446) confirm this by stating that the main aim of in-service training is to empower psychiatric nurses with knowledge, skills and positive attitudes so that they can perform their duties according to set standards.

\section{Social advantages}

The social advantages of in-service training raised by participants were: gaining respect from others (eight reports) and understanding how to relate with others (two reports). The following quotes illustrate this theme:

'If we know what we are doing we are going to yield positive results and we are going to get the respect from the community ... building on the reputation of the hospital. Also from inservice training you get to know how to deal with subordinates so that the environment becomes conducive to all and we work harmoniously without conflicts ... and we are all happy.' (f2, p7)

'... [Y]ou gain respect because people realise that you are well informed...' (f2, p4)

Burton and Ormrod (2011:161) report that the relationship between psychiatric nurses and other multi-disciplinary team members can be observed by the formality and informality placed on the learning and teaching relationship, the nature of support that is fostered and the nature of trust in the psychiatric nurses' knowledge and skills. The relationship between superiors and subordinates is improved because of continuous in-service training (Erasmus et al. 2009:235).

\section{Physical advantages}

The physical advantages of in-service training raised by participants were: a decrease in staff injuries (six reports) and in patient injuries (seven reports). The following quotes illustrates this theme:

'I think in-service training is a need in psychiatric nursing, the reason being that we are dealing with patients that you can expect anything from them; you cannot say I know the patient. If you do things correctly, knowing the correct procedure after in-service training let me say for example physically there is a course called calming and restraining ... you do not end up hurting the patient or hurting yourself.' (f4, p4)

'... [I]n-service training has helped me a lot professionally ... I can figure out that the patient is a danger to himself and others and I will make sure that he does not injure himself or others.' (f2, p6)

Literature reports that working in a psychiatric hospital is a challenge for psychiatric nurses because patients can be aggressive and direct their anger at staff members and at other patients (Willets \& Leff 2003:237). Therefore, in-service training helps psychiatric nurses to share information and skills in order to deliver quality services to patients and their families, thus leading to a reduction in patient injuries (Kneisl \& Trigoboff 2009:22). 


\section{Psychological advantages}

The psychological advantages of in-service training raised by participants were: a feeling of more confidence (10 reports) and an increased ability to manage stress and anxiety (five reports). The following quotes demonstrate this theme:

'One becomes developed and gain some confidence [sic], when you walk out of the training and ... there is that kind of feeling that you can add value to the institution. In-service training in line with new aspects of work and one of them being to catch with new developments like new technologies, new research and so forth ... not getting in-service training one start to develop fear.' (f1, p5)

'... [O]nce you are informed you tend to be relaxed, even in extreme cases ...' (f2, p4)

'... [O]ne becomes confident and when you are confident there is less stress ...' (f3, p3)

Erasmus et al. (2009:4) confirm that in-service training helps psychiatric nurses to handle stress, tension and conflict more effectively, which increases their confidence. Booyens (2008:386-390) confirms this theme, stating that in-service training helps psychiatric nurses to relate informally to each other and to enjoy the fellowship of their colleagues, so increasing confidence in practice.

\section{Theme 3: Challenges with regard to in-service training}

The participants indicated that there were challenges with regard to in-service training and this theme includes the aspects that hinder in-service training and possible recommendations provided by the participants in order to improve in-service training.

\section{Aspects which hinder in-service training}

Participants mentioned the following aspects as being hindrances to in-service training: the needs of staff were neglected (four reports), a lack of staff motivation (four reports), repetition of the same topics (four reports), limited opportunities for staff to express their needs with regard to in-service training (three reports), limited resources (five reports) and a lack of planning (three reports). The following quotes support this theme:

'So people's needs are also been neglected or being weighed; they should know this and why doesn't she know that. You find that need analysis have been conducted and people are requested to provide the topics and the very same old topics are written over and over again. There are people whom when you are talking about in-service training you are talking about a monster.' (f3, p7)

'... [T] he motivation of staff members - if the staff members think the topic is not related to their scope of practice and it is not interesting then the in-service training attendance will be poor.' (trial run, p7)

Literature reports that a common mistake which is made by inservice trainers is trying to share knowledge and experience with people who are not ready to learn (Abruzzese 1996:284). Nel et al. (2005:451) agree, stating that adults prefer to plan their own learning projects and to adopt a self-directed approach towards learning.

\section{Recommendations for the improvement of in-service training}

Participants recommended the following for the improvement of in-service training: the involvement of staff members regarding the needs for in-service training (14 reports), relevant training based on needs (10 reports), recent and interesting topics (five reports), exemplary and proactive management (six reports), in-ward in-service training (five reports), centralised in-service training (four reports), improvement of presentation on the part of the trainers (four reports), learning resources should be made available (four reports), planning for in-service training (five reports) and inviting external presenters or experienced presenters (four reports). The following quote relates to this theme:

'We should invite motivational speakers on our plan like last time we were talking about topics do a survey and people chooses the topics people would like to attend. I think people get bored to listen to one in-service training [topic] down there. I think if they may try; do more research about crime and the new treatment people may develop interest to come to in-service trainings.' (f2, p8)

Muller (2009:351) confirms that assessment of the learning needs should be done, including the circulation of a list to identify the learning needs of psychiatric nurses according to their personal preferences. In-service training must be task- and results-oriented, should focus on enhancing those specific skills and abilities needed to perform the job and must make a real contribution to the improvement of the quality of psychiatric nursing care (Van Dyk et al. 2001:150). The involvement of competent trainers will have an impact on how the psychiatric nurses experience in-service training (Norushe et al. 2004:70).

\section{Ethical considerations}

Permission to conduct the research was granted by the North-West University (NWU) Ethics Committee (NWU00100-10-S1). Permission was also requested with regard to conducting the study in the Gauteng Province and in the selected psychiatric hospital, both of which were granted. The researchers aimed to protect participants from discomfort and harm. In this study, participants received increased knowledge about the needs and benefits of inservice training for psychiatric nurses and an increased understanding of how in-service training improves service delivery. Participants were unable to perform their routine activities as usual on the days of data collection (Brink, Van der Walt \& Van Rensburg 2012:40), however, relief from duties for the duration of data collection was arranged with the nursing service manager. Support services were put in place for participants who may have experienced some psychological distress when describing their personal views about in-service training needs of psychiatric nurses (Brink et al. 2012:40).

The participants were made aware of the fact that participation in the study was voluntary and that there was 
no risk of penalty or prejudicial treatment for refusing to participate. The right to self-determination was respected and was ensured by informing participants about their right to participate or withdraw from taking part in the study (Brink et al. 2012:43). Thorough explanations were given to possible participants in this study and informed consent was requested for their participation in this research. The informed consent form included the purpose of the study, the target population, methods and procedures that would be used to collect data, description of the possible risks and discomforts, how data would be handled in order to ensure confidentiality, the name of a contact person and that tape recorders would be used to record interviews. Information was given at the participants' own level of understanding and in their own language. Feedback was requested from participants in order to ensure that they understood all the information provided. Flyers were also used to reinforce the understanding of the study information.

In this research, participants who were involved in and knowledgeable about in-service training were selected. The participants were made aware of their rights and those who were willing to participate in the study signed a consent form. All the participants were selected according to the selection criteria. Participants were treated equally and without any form of discrimination. The participants' privacy was ensured by keeping information confidential, ensuring that the audio recordings and transcripts of the interviews were kept under lock and key and ensuring that no one had access to them except the researcher and his supervisors. All electronic data were kept on a password-protected computer. Anonymity was ensured by avoiding the use of participants' actual names (Brink et al. 2012:41).

\section{Trustworthiness}

Trustworthiness was ensured by means of the criteria of credibility, transferability, dependability and confirmability. According to Lincoln and Guba (1985:80), the key principle of good qualitative research is found in the notion of trustworthiness. A quantitative study cannot be deemed valid unless it is reliable, qualitative study cannot be called transferable unless it is credible and it cannot be considered credible unless it is dependable. Table 1 provides details with regard to how these criteria were ensured.

\section{Discussion}

\section{Nursing education}

The findings of this research can add value to nursing education if they can be included in the basic nursing curriculum offered at colleges and universities. According to the participants in this research, in-service training should not be the responsibility of only the professional nurses or unit managers, but of all the nursing staff in the unit, including students. The focus should not be only on the importance of in-service training, but also on needs identification and the presentation of in-service training. If all the categories of nurses know what in-service training is, its importance and how they will benefit from either presenting or attending, this will improve the planning and conducting of in-service training.

\section{Nursing research}

Research was conducted in only one psychiatric hospital in Gauteng and it is recommended that the study be conducted on a larger scale. Another study could be done on the implementation of the suggested in-service training recommendations.

\section{Nursing practice}

Recommendations for nursing practice were developed from question three of the interview schedule, namely 'What can be done to ensure that in-service training is done continuously?'. The theme 'Challenges in in-service training' and its subthemes, namely 'Recommendations for the improvement of in-service training' and 'Aspects which hinder in-service training', were divided into five main categories, namely: needs assessment; management involvement; planning; varied topics; and presenters and resources. The theme and subthemes were addressed under these categories. In Table 2, the five main categories are operationalised, so as to provide recommendations for in-service training.

\section{Conclusion}

The objectives as stated were attained. The findings confirmed the need for ongoing in-service training which has career, social, physical and psychological advantages for psychiatric nurses. Aspects that hinder in-service training need to be addressed by planning ahead and by implementing the recommendations as identified by the psychiatric nurses and their managers. The recommendations that were developed from the findings can be viewed as relevant and valuable and will make a positive change in the psychiatric setting if implemented by both management and the psychiatric nurses.

TABLE 1: Trustworthiness.

\begin{tabular}{|c|c|c|}
\hline Criteria & Strategy & Technique \\
\hline Truth value & Credibility & $\begin{array}{l}\text { Focus group interviews done with different groups of psychiatric nurses. } \\
\text { One to two hours spent with each group. } \\
\text { Member checking was done with psychiatric nurses after data collection. } \\
\text { Written summaries of collected data, categories and interpretations were discussed with experts in nursing research at North-West University. }\end{array}$ \\
\hline Applicability & Transferability & $\begin{array}{l}\text { Training coordinator at selected psychiatric hospital assisted in selecting psychiatric nurses. } \\
\text { Data were collected and analysed continuously until they became repetitive and ineffective. } \\
\text { Information regarding research design and methods used was described densely. }\end{array}$ \\
\hline Confirmability & Dependability & A co-coder with experience in co-coding qualitative studies confirmed the researcher's findings. \\
\hline
\end{tabular}


TABLE 2: Recommendations for in-service training for psychiatric nurses ( $T=$ theme; $S=$ subtheme).

\begin{tabular}{|c|c|c|}
\hline Categories & Operationalisation & $\begin{array}{l}\text { Items from } \\
\text { question } 3\end{array}$ \\
\hline Needs assessment & $\begin{array}{l}\text { - Staff development officer (SDO) should form an in-service training committee which consists of all categories of nurses to assess, plan, } \\
\text { analyse, implement and evaluate in-service training programmes. } \\
\text { - The in-service training committee should develop an in-service training needs assessment form. } \\
\text { - The SDO should circulate the developed in-service training needs assessment form, so that psychiatric nurses can indicate their needs } \\
\text { for in-service training on a yearly basis. } \\
\text { - Other needs assessment methods should also be used to ensure that nurses have sufficient methods of expressing their in-service } \\
\text { training needs e.g. suggestion boxes. } \\
\text { - Nurses must sign for receipt of the in-service training needs assessment forms and when they return the forms. The SDO must make } \\
\text { sure all the nurses in the hospital have received forms and that all of them have returned their forms. } \\
\text { - The in-service training committee must categorise the in-service training needs according to their importance and determine the topics } \\
\text { that could be discussed at ward level and centrally. } \\
\text { - The SDO must inform nurses about the decision the in-service training committee made regarding the topics for in-service training. }\end{array}$ & $\begin{array}{l}\text { T1 S1 } \\
\text { T1 S2 } \\
\text { T2 S1 } \\
\text { T2 S4 }\end{array}$ \\
\hline $\begin{array}{l}\text { Management } \\
\text { involvement }\end{array}$ & $\begin{array}{l}\text { - The nursing manager should act proactively to resolve pending problems by suggesting topics which will empower nurses to function } \\
\text { effectively. } \\
\text { - The nursing manager should add topics that were omitted; which in his/her view are important for all nurses to render quality nursing } \\
\text { care in the hospital. } \\
\text { - The nursing manager should authorise centralised in-service training based on the recommendations provided by the in-service training } \\
\text { committee. } \\
\text { - The nursing manager and in-service training committee should explore partnerships with universities so as to increase accessibility to } \\
\text { experts in the different fields of health science. } \\
\text { - The nursing manager must also attend in-service training and present topics to nurses as an example to subordinates. } \\
\text { - The management of the hospital should design a way of rewarding nurses who present and actively participate in in-service training. } \\
\text { - The management of the hospital should correlate effective in-service training programmes with quality patient care and cost } \\
\text { effectiveness in the hospital. }\end{array}$ & $\begin{array}{l}\text { T1 S4 } \\
\text { T1 S10 }\end{array}$ \\
\hline Planning & $\begin{array}{l}\text { - In ward in-service training should be planned every month in consultation with the unit manager and venues booked accordingly. } \\
\text { - The centralised in-service training programme should be planned on a yearly basis in consultation with the nurse manager and venues } \\
\text { booked accordingly. } \\
\text { - The in-ward in-service training programme should be made available a month in advance so that presenters can prepare for the session. } \\
\text { - The centralised in-service training programme should be made available a year in advance so that external presenters can be invited to } \\
\text { present and internal presenters can be prepare for the session. } \\
\text { - In service training programmes should be presented at times and dates that are convenient for nurses to attend e.g. nurses common day } \\
\text { on duty. } \\
\text { - All in-service training programmes should be made accessible to all the nurses in the hospital e.g. placed on notice boards in the wards. } \\
\text { - Preparations and presentations should be done in pairs in the ward, the experienced presenter paired with an inexperienced presenter } \\
\text { to empower the inexperienced. } \\
\text { - The SDO should keep records of topics discussed centrally and in the wards. At the end of each in-service training session the presenter } \\
\text { should be evaluated by the attendants. The evaluation form and attendance list should be submitted to the SDO for further planning. } \\
\text { - The in-service training committee should meet regularly to evaluate the in-service training programme and to identify problems, and } \\
\text { intervene accordingly. }\end{array}$ & $\begin{array}{l}\text { T1 S2 } \\
\text { T1 S5 } \\
\text { T1 S6 } \\
\text { T1 S7 } \\
\text { T1 S9 } \\
\text { T2 S6 }\end{array}$ \\
\hline $\begin{array}{l}\text { Varied topics and } \\
\text { presenters }\end{array}$ & $\begin{array}{l}\text { - The in-service training committee should reviews topics discussed centrally and in the wards to determine which topics could be } \\
\text { repeated. Topics must never be repeated unless there is a need to do so. } \\
\text { - The in-service training committee in consultation with the nursing manager should decide on the topics which could be presented by } \\
\text { experts from outside the hospital. } \\
\text { - Internal presenters who are good at presenting must be given opportunities to present centrally, while those that are still developing } \\
\text { their presentation skills should be limited to presentation in the ward. }\end{array}$ & $\begin{array}{l}\text { T1 S3 } \\
\text { T1 S10 } \\
\text { T2 S3 } \\
\text { T2 S2 }\end{array}$ \\
\hline Resources & $\begin{array}{l}\text { - The in-service training committee in consultation with the nursing manager should explore partnerships with universities and access to } \\
\text { resources like psychiatric nursing related journals, textbooks, and experts in different health care sciences. } \\
\text { - The in-service training committee in consultation with the nursing manager should explore access to computers and the internet for } \\
\text { presenters. } \\
\text { - Presenters should be encouraged to deliver power point presentation and provide compact discs or note pages/copies of the } \\
\text { presentation. } \\
\text { - Presenters who cannot make power point presentations should be encouraged to use chalk boards, overhead projectors and flip charts. }\end{array}$ & $\begin{array}{l}\text { T1 S8 } \\
\text { T2 S5 }\end{array}$ \\
\hline
\end{tabular}

\section{Acknowledgements}

The authors will like to thank the participants who shared their experiences willingly.

\section{Competing interests}

The authors of this article declare that they have no financial or personal relationship(s) which may have inappropriately influenced them in writing this article.

\section{Authors' contributions}

H.R.L. (Ann Latsky Nursing College) conducted the research and drafted the manuscript. M.P.K. (North-West University) and S.K.C. (North-West University) were the research supervisor and co-supervisor, respectively, and corrected and refined the manuscript. V.K. (North-West University) assisted with data analysis and with the writing and formatting of the manuscript.

\section{References}

Abruzzese, R.S., 1996, Nursing staff development: strategies for success, Mosby, Michigan.
Bloor, R., McHugh, A., Pearson, D. \& Wain, I., 2004, 'A training course for psychiatric nurses in Russia', Nursing Standard 18(39), 39-41. http://dx.doi.org/10.7748/ ns2004.06.18.39.39.c3626

Booyens, S.W., 2008, Introduction to health services management, 3rd edn., Juta and Company Ltd, Cape Town.

Brink, H., Van der Walt, C. \& Van Rensburg, G., 2012, Fundamentals of research methodology for health care professionals, 3rd edn., Juta and Company Ltd, Cape Town.

Burns, N. \& Grove, S.K., 2005, The practice of nursing research: Conduct, critique, and utilization, 5th edn., Elsevier/Saunders, St Louis, MI.

Burns, N. \& Grove, S.K., 2009, The practice of nursing research: Appraisal, synthesis, and generation of evidence, 6th edn., Elsevier/Saunders, St Louis, MI.

Burton, R \& Ormrod, G., 2011, Nursing: Transition to professional practice, Oxford University Press, New York.

Creswell, J., 1994, Research design: Qualitative and quantitative approaches, Sage Publications, London.

Delport, S.V., Greenfield, D.H. \& Carolus, S.E., 1989, 'Midwives' in-service training in newborn-care in the Cape', Nursing RSA 4(1), 26-27.

Erasmus, B., Loedolff, P., Mda, T. \& Nel, P, 2009, Managing trainging and development in South Africa, Oxford University Press, Cape Town.

Frenk, J., Chen, L., Bhutta, Z.A., Cohen, J., Crisp, N., Evans, T. et al. 2010, 'Health professionals for a new century: Transforming education to strengthen health systems in an interdependent world', The Lancet 376(9756), 1923-1958. http:// dx.doi.org/10.1016/S0140-6736(10)61854-5

Gournay, K., 2000, 'Role of the community psychiatric nurse in the management of schizophrenia', Advances in Psychiatric Treatment 6, 243-249. http://dx.doi. org/10.1192/apt.6.4.243

Harrington, D.C., 1989, 'Inservice education and staff development at a private hospital', Nursing RSA 4(10), 28-31.

Keltner, N.L., Bostrom, C.E. \& McGuinness, T., 2011, Psychiatric nursing, 6th edn., Elsevier, St. Louis, MI. 
Kneisl, C.R. \& Trigoboff, E., 2009, Contemporary psychiatric-mental health nursing, Pearson Education, New Jersey.

Lam, D.H., Kuipers, L. \& Leff, J.P., 1993, 'Family work with patients suffering from schizophrenia: The impact of training on psychiatric nurses' attitude and knowledge', Journal of Advanced Nursing 18(2), 233-237. http://dx.doi. org/10.1046/j.1365-2648.1993.18020233.x

Lincoln, Y.S. \& Guba, E.G., 1985, Naturalistic inquiry, SAGE publications, California.

Macnee, C.L., 2004, Understanding nursing research: Reading and using research in practice, Lippincott Williams \& Wilkins, Philadelphia.

Morgan, D.L., 1998, The focus group guidebook, Sage Publications, London. http:// dx.doi.org/10.4135/9781483328164

Muchinsky, P., Schreuder, D. \& Kriek, H.J., 2003, Personnel psychology, Oxford University Publishers, Cape Town

Muller, M.E., 2009, Nursing dynamics, 4th edn., Heinemann Publishers, Cape Town.

Munro, A., Watson, H.E. \& McFadyen, A., 2006, 'Assessing the impact of training on mental health nurses' therapeutic attitudes and knowledge about co-morbidity: 1430-1438. http://dx.doi.org/10.1016/j.ijnurstu.2006.07.024

Needham, I., Abderhalden, C., Halfens, R.J.G., Dassen, T., Haug, H.J. \& Fischer, J.E., 2005 'The effect of a training course in aggression management on mental health nurses' perception of aggression: A cluster randomised controlled trial', International Journal
of Nursing Studies 42(6), 649-655. http://dx.doi.org/10.1016/j.ijnurstu.2004.10.003
Nel, P.S., Van Dyk, P.S., Haasbroek, G.D., Schultz, H.B., Sono, T.J. \& Werner, A., 2005, Human resources management, 6th edn., Oxford Üniversity Press, Cape Town.

Nel, Z.J.C., 1986, 'The effect of in service training on the quality of psychiatric nursing to mentally retarded persons', unpublished Master's dissertation, Department of Nursing, Faculty of Health Science, Rand Afrikaans University, Johannesburg.

Norushe, T.F., Van Rooyen, D. \& Strumpher, J., 2004, 'In-service education and training as experienced by registered nurses', Curationis 27(4), 63-72. http://dx.doi. org/10.4102/curationis.v27i4.1022

Polit, D.F. \& Beck, C.T., 2006, Essentials of nursing research: Methods, appraisal, and utilization, 6th edn., Lippincott-Raven Publishers, Philadelphia.

Statistics South Africa, 2011, Statistics by place, viewed 16 January 2012, from http:// beta2.statssa.gov.za/?page_id=964

Swanepoel, B.J., Erasmus, B.J. \& Schenk, H.W., 2008, South African human resource management: Theory \& practice, 4th edn., Juta and Company Ltd., Cape Town.

Uys, L.R. \& Middleton, L., 2004, Mental health nursing: A South African perspective, Juta and Company Ltd, Cape Town.

Van Dyk, P.S., Nel, P.S., Van Z Loedolff, P. \& Haasbroek, G.D., 2001, Training management: A multi-disciplinary approach to human resources development in South Africa, 3rd edn., Oxford University Press, Cape Town.

Willets, L. \& Leff, J., 2003, 'Improving the knowledge and skills of psychiatric nurses: Efficacy of a staff training programme', Journal of Advanc 